\title{
Beyond the Band of Brothers - the US Military and the Myth that Women can't fight
}

\section{Megan Mackenzie}

\section{Cambridge University Press, 2015.}

Anmeldt av Lena P. Kvarving ${ }^{\star}$, Oberstløytnant, Forsvarets Høgskole

Kvinner og menn er ulike, og ulikhetene har i mange situasjoner og i umåtelig lang tid blitt brukt som et argument for å bevare menns privilegier og forpliktelser. Gradvis har rettferdighet og likeverd heldigvis vunnet plass på mange arenaer, men det militære domenet har forblitt et av de mest krevende å endre i så måte. Spørsmålet er om motkreftene skyldes dokumenterte fakta som understøtter at «women can't fight» eller om det er andre mekanismer som hindrer utviklingen av militæret og muligheter for at kvinner kan bidra til de forpliktelser og nyte godt av de privilegier som de væpnede styrker representerer.

Dr. Megan Mackenzie fra Universitetet i Sydney er en ledende ekspert på fagområdet knyttet til kjønn, sikkerhet og kvinner i militæret. I denne boken gir hun en systematisk og grundig analyse av kvinners rolle i det amerikanske militæret, militære kampoperasjoner og hovedargumentene som har vært brukt til å underbygge ekskludering av kvinner i kamp og kampavdelinger.

Gjennom en historisk analyse av det amerikanske forsvaret, myten om at kvinner ikke strekker til og rollen «the band of brothers» har i den forbindelse, presenterer Dr. Mackenzie en overbevisende utredning og forståelse av dynamikken knyttet til kjønn i det militære. Hun diskuterer ikke om inkludering av kvinner ville ha en positiv eller negativ effekt, men bruker ekskluderingen som et verktøy til å forstå den militære identiteten. Hun argumenterer overbevisende om at ekskluderingen egentlig aldri har handlet om kvinnene, men om mennene selv. Dette forklarer hun gjennom to fokus. Det første handler om at ekskluderingen hadde og har fundament i utviklingen av regler og ideer som først og fremst handler om rettferdiggiøring og beskyttelse av en ren mannlig kampenhet som det eneste riktige, avgjørende og enestående. I tillegg har ikke ekskluderingen av kvinner vært basert på forskning eller bevis i forhold til kvinner og krig, men vært fundamentert på og opprettholdt

^Korrespondanse: Lena P. Kvarving, Forsvarets Høgskole. Email: 1kvarving@gmail.com 
av fantasihistorier, myter og følelsesmessige argumenter. Spesielt har myten om «the band of brothers» bidratt til en oppfatning om hva menn og kvinner kan eller burde gjøre i krig.

Dr. Mackenzies analyser blir gjennom hele boken belyst av gode eksempler og motsetninger i det amerikanske militæret, som er til både ettertanke og bekymring. Som eksempel ble det brukt som argument for å holde kvinner unna kamp at det var større sannsynlighet for at de ville bli tatt til fange og voldtatt og at dette ville påvirke den allmenne moralen og være mye mer demoraliserende for den vanlige amerikaner enn om det skjedde med mannlige soldater. Om kvinner er mer sårbare er vanskelig å underbygge. To kvinnelige soldater ble holdt som krigsfanger under Den persiske Gulf-krigen, mens de eneste rapporterte voldtektssaker og seksuelle overgrep mot kvinnelige soldater ble utført av deres amerikanske medsoldater.

Og som Mackenzie sier er det også verdt å merke seg at argumentet er bygget på følelser som frykt, og avhenger av mulige trusler og reaksjoner, ikke bevis for det ene eller det andre. I nyere tid har det også blitt rapportert at nærmere halvparten av alle kvinnene som tjenestegjorde i Irak og Afghanistan, ble seksuelt trakassert. I den amerikanske hæren generelt har en av fire tjenestekvinner blitt seksuelt trakassert, og det er videre rapportert at mellom 20 og 40 prosent kvinnene i det amerikanske forsvaret har opplevd voldtekt eller voldtektsforsøk av noen i egne styrker i løpet av deres militære karriere. Og dette er selv om det amerikanske forsvarsdepartementet mente at omtrent 80 prosent av alle tilfellene ikke ble anmeldt.

Boken viser også til mange eksempler på hvordan kvinner faktisk har blitt brukt i kamp i flerfoldige år, men at det likevel har vært argumentert hardt for et fortsatt formelt forbud om kvinners deltakelse i kamp. Dette selv om frontlinjene for lengst er omdefinert i lys av terrorister og opprørere, som i realiteten gjør at også tidligere støttefunksjoner i praksis er midt i striden. Kvinner har også blitt dekorert med «Purple Heart» for deres innsats i strid, kvinner har blitt brukt i nyopprettede «Female Engagement Teams» for å unngå reglementet om kvinner i strid. Likevel har det blitt argumentert hardt for å opprettholde oppfatningen om at de er og bør forbli ekskludert fra stillinger i strid. Som en konsekvens har dette også forhindret kvinner i å gjøre karriere, i og med at stridsstillinger har vært en forutsetning for avansement.

Mackenzie understreker at følelser i seg selv ikke er et problem når man tenker på policy, men om man overser rollen og verdien følelser spiller og har, så virker det ødeleggende på policy-prosesser og hvorfor de blir støttet. Ekskludering av kvinner har blant annet blitt argumentert for på bakgrunn av at «det føles bare feil», «det er Guds vilje», «det er unaturlig» eller «det er en kvinnes plikt å gi liv, ikke ta dem» og at de kvinner som tar slike roller derfor er «moralsk korrupte». Disse og flere argumenter viser ulike følelser av frykt, som tap av roller, identitet og feil rekruttering, og de har blitt uttrykt av aktører på høyeste nivå både politisk og militært.

Det mest debatterte elementet knyttet til kvinner i strid har vært deres fysiske kapasitet, og forfatteren argumenterer med at heller ikke disse argumentene er så rett fram som de kan høres ut. Det er et stort sprang fra å påstå at kvinner er svakere enn menn, til å påstå at en slik ulikhet nødvendigvis ikke gjør kvinner i stand til å fylle 
stridsroller. Det innebærer jo en antagelse om at ulikheten er uoverkommelig, det vil si at biologi er skjebnen og ikke kan overkommes med trening eller tilpassede oppgaver. I tillegg ligger det en antakelse om at strid krever unike fysiske ferdigheter som ikke trengs $\mathrm{i}$ andre militære roller og at kvinner mangler disse bestemte ferdighetene. Mackenzie viser til forskning som understreker at biologien slett ikke er avgjørende, men at trening, utstyr tilpasset kvinner, en gjennomgang av testbatteriet og et oppgjør knyttet til myter omkring kvinner, menstruasjon, graviditet og morsrolle kan være nødvendig. Argumenter som at kvinner har for stort fravær av disse biologiske årsakene har blitt møtt med motargumenter om at dette er uproblematisk, av en pensjonert admiral som sier at «det er mye større disiplinære problemer med menn, uautorisert fravær, fravær på grunn av seriøse lovbrudd og så videre, så fravær på grunn av graviditet er ingenting $\mathrm{i}$ forhold».

Det siste argumentet Mackenzie tar for seg er at kvinner ødelegger det nødvendige samholdet. Soldater i strid skal ikke bare like hverandre og ha etablerte bånd, men vere like og ha like verdier og delt identitet. Det har mindre med effektivitet, tillit og økt nasjonal sikkerhet å gjøre, enn med opprettholdelse av myten om den ideelle soldat og ekte krigføring som krever at kvinner er de underordnede utenforstående som trenger beskyttelse. Dette argumentet har også tidligere blitt brukt for å holde andre minoritetsgrupper som svarte eller homofile unna strid. Kvinner har blitt sett på som en trussel for samholdet, ikke fordi de ikke kan løse oppdragene, men fordi de er ansett som ute av stand til å bygge opp båndet som finnes mellom menn. Det er derfor ekstra urovekkende at mange tolkninger av dette samholdet prioriterer menns «bonding» fremfor effektivitet i strid. Ikke bare fremstår det som dette samholdet fremhever maskulinitet som en forutsetning, men ser ut til å kreve ekskludering og til og med nedgradering av kvinner. Mackenzie henviser til at forskning understøtter at det virkelige samholdet ikke forårsakes av likhet, men skapes gjennom lederskap, trening og arbeid for å bedre holdninger.

På bakgrunn av sine analyser mener Dr. Mackenzie derfor at inkludering av kvinner i strid rører ved selve den «Hellige gral» av militær kultur og at avgjørelsen om å heve forbudet mot å ekskludere kvinner fra kamp slik det ble gjort i 2013, ikke nødvendigvis må betraktes som et stort fremskritt for likeverd, men muligens mer som et forsøk på å redefinere og gjenopplive det maskuline bildet av militæret og skape en fornyelse av eventyret om «the band of brothers». Det å gi rom for noen få utvalgte og gi inntrykk av at forsvaret er en inkluderende organisasjon, er med på å flytte fokuset bort fra det økende antall hendelser hvor amerikanske soldater er assosiert med brudd på menneskerettighetene, seksuell vold og andre ulike skandaler.

Boken er et resultat av et solid forskingsarbeid, og den formidler glimrende og objektive analyser. Selv om Mackenzie har forsket på det amerikanske forsvaret, så vil det være mange og kjente argumenter som også har blitt og blir brukt i Norge og andre allierte militære styrker. Boken har derfor nyttig overføringsverdi til norske forhold og burde være pensum på Forsvarets skoler hvor militære offiserer og ledere vil kunne få et innblikk i hvilke mekanismer og holdninger som kan være tilstede i deres militære organisasjon, og kanskje sågar i dem selv. Skal de kunne lede og 


\section{Lena P. Kvarving}

utvikle en formålstjenlig organisasjon både strukturelt, funksjonelt og kulturelt må det være basert på forskning og gode erfaringer, ikke myter og følerier. Boken passer også for forskere i militære studier, «kjønnstudier», og de som driver med utviklings- og policyarbeid i det norske Forsvaret. 